УДК 78. 071. 1(510) (092) : [784:785. 11]

DOI 10. 34064/khnum1-6007

\title{
Хуан Лей
}

аспірант кафедри інтерпретології та аналізу музики

Харківського національного університету мистецтв

імені І. П. Котляревського

e-mail: 1908278607@qq.com

ORCID iD: 0000-0001-9227-8429

\section{ГЕРОЇЧНА ПАСТОРАЛЬ ТА ЇЇ НАЦОНАЛЬНО-СТИЛЬОВА РЕЦЕПЦІЯ В КАНТАТІ СЯНЬ СІНХАЯ «ХУАНХЕ»}

Розглядається художня концепџія відомого твору китайської музичної класики ХХ століття, яка увиразнює, з одного боку, патріотичну ідею, а з іншого - містить образ людини пасторальної. Виявлення сталих домінант китайської музичної мови в кантаті вказує не лише на героїчну семантику, але й на наявність емблематики пасторального жанру. Про ознаки пасторалі свідчить, в першу чергу, тяжіння до звукозображсальної символіки, пов'язаної з образами природи, які посідають паритетне місие поряд з героїчними образами. Трактування кантати як героїчної пасторалі збігається з раннім (бароковим) етапом функиіонування жанру (ораторії Г. Ф. Генделя), коли було закладено комплекс інваріантних елементів музичної мови. Домінантними ознаками китайської пасторалі в кантаті Сянь Сінхая є наявність колективного герою (народ), пантеїзм як філософія любові до природи, одичний дух радості, лірико-споглядальний світогляд, щчо в иілому дозволяє провести історико-культурну паралель між європейським мистецтвом та національною класикою Китаю.

Ключові слова: кантата; художня концепчія жанру; героӥчна пастораль; наративна драматургія; звукозображальна символіка.

Постановка проблеми. Кантата «Хуанхе» (黄河 - «Жовта ріка») $\epsilon$ одним з найбільш визначних творів професійного музичного мистецтва Китаю. Створена 1939 року композитором Сянь Сінхаєм (冼星海) 
на текст поеми Гуан Вейжаня (光未然), у наш час вона не втратила своєї актуальності не тільки через національний колорит, але й завдячуючи майстерності композиторського письма. Поетичний текст кантати створений Гуан Вейжанем 1938 року (за рік до написання музики). В ньому йдеться про важкі часи боротьби китайського народу з японськими окупантами під час Другої китайсько-японської війни. Тема сьомої частини твору - «Захистимо Хуанхе» - стала гімном національно-визвольного руху, а друга частина - «Ода річці Хуанхе» - $є$ однією з найулюбленіших у китайської публіки. Перед українським слухачем, як і перед будь-яким європейцем, постає проблема розуміння інонаціональної музичної мови. Художня концепція жанру пасторалі як гармонійного спілкування людини з природою задля розв'язання етичних та сочіальних проблем (див. Shapovalova, L. \& Chernyavska, M. \& Govorukhina, N. \& Nikolaievska, Yu., 2021) дозволяє залучити етнонаціональну мову цього твору в систему європейських загальнолюдських цінностей; отже, через вивчення базових принципів музичної мови різних культур актуалізувати семіосферу «Схід - Захід» як для виконавців, так і для слухачів.

Сфера героїки в добу європейського Бароко та Класицизму була тісно пов'язана з ідеалами людини, яка виборює ідеали суспільства (і навіть гине заради них), в той час як пастораль увиразнювала образи природи, яка слугувала прекрасними «декораціями» людських діянь. Актуальність теми підсилює інтерес до проблеми спілкування людей в глобалізованій ойкумені, зокрема, трактування композитором жанрової семантики кантати в світлі концепції людини героӥчної в поєднанні з ідеєю пантеїзму як філософії людини пасторальної. 3 одного боку, таке визначення музичної семантики не видається дивовижним, незвичним, принаймні, з урахуванням історично усталеної символіки національно-поетичного мислення китайської культури, в якій переважають образи природи. 3 іншого боку, інтерпретативний (герменевтичний) аналіз музично-поетичного тексту кантати Сянь Сінхая викликає певні аналогії з історією європейської традиції героїчної пасторалі, пов'язаної з показом людини суспільної (homo communis) як частки природи. Йдеться не про стилізацію картин природи (музичний звукопис), а про історико-культурну паралель, що відповідає «діалогу культур» як провідної тенденції сучасного мистецтва. 
Мета статті - виявити ознаки пасторального жанру в кантаті Сянь Сінхая «Жовта ріка» через усталений комплекс китайської національної мови.

Аналіз останніх публікацій за темою. Методологія дослідження музичного стилю кантати віддзеркалюється в працях китайських вчених (у тому числі жанрової версії концерту для фортепіано з оркестром). Так, у дисертації Шан Бая (Shan Bai, 2006) виявлено принцип будови концерту для фортепіано «Жовта ріка», що запозичує тематизм кантати (другий розділ дисертації присвячений саме кантаті, а третій - концерту).

Дисертація Сьєнтан Хон (Xiangtang Hong, 2009) також є дотичною до теми пропонованої статті. 3400 сторінок праці під назвою «Виконання кантати “Жовта ріка”» 65 сторінок авторка присвячує історії створення кантати та виконання іiі за кордоном, перекладу вербального тексту (з китайської на англійську), надає транслітерацію латиною, список творів Сянь Сінхая, відомості щодо різних редакцій твору (1. 1939, Yan’an, Xian Xinghai; 2. 1941, Moscow, Xian Xinghai; 3. 1946, USA, Wallingford Riegger; 4. 1955, Shanghai, Li Huanzhi; 5. 1975, Beijing, Yan Liangkun; 6. 2005, Hongkong, Carmen Koon (Xiangtang Hong, 2009: 5), а також опис китайських народних інструментів, використаних у партитурі (там само: 54-56).

У дисертації Сьєнтан Хон (Xiangtang Hong, 2009: 43-44) вміщено таблицю складу оркестру в двох варіантах: 1939 року (Сннань) та 1941 року (Москва) - варіант, що аналізується нами. Досить влучними видаються жанрово-виконавські визначення кожної з частин циклу: 1. Song of the Yellow River Boatmen (змішаний хор); 2. Ode to the Yellow River (чоловіче соло); 3. Yellow River's Water from Heaven Descends (речитативна пісня); 4. Yellow Water Ballad (унісон); 5. Musical Dialogue on the River Bank (дует); 6. Yellow River Lament (жіноче соло); 7. Defend the Yellow River (канон); 8. Roar! Yellow River (змішаний хор) (там само: 6).

У дослідженні Чунья Чан (Chang, Chun-ya, 2017) висвітлено зміст фортепіанного концерту, написаного на музичному матеріалі кантати; йдеться про впливи на композитора західноєвропейського мислення (що проявилося, зокрема, в другій, московській, редакції твору). 
Отже, жанровий зміст твору розглядається китайськими дослідниками в системі засобів музичної виразності (ширше - композиторського мислення), а не в жанровій традиції (будь-якій).

Втім, вказані джерела не вичерпують усієї повноти бачення сnеuиффіки музичної семантики жанру. Гіпотеза щодо кантати «Хуанхе» як китайської версії героїчної пасторалі, що відповідає історичній генезі європейської традиції жанру, обумовлює наукову новизну розкриття теми пропонованої статті.

Методи дослідження. Окрему проблему становить специфіка національно-музичної мови як такої, що уособлює образ Китаю через концепт людини пасторальної («природа - людина»). Тому в статті автором апробується когнітивно-інтерпретативний підхід, що розробляється кафедрою інтерпретології та аналізу музики Харківського національного університету мистецтв імені І. П. Котляревського (Шаповалова, 2017). Вивчення національно-мовної специфіки кантати в єдності з жанрово-стилістичним та драматургічним аналізом циклу (зокрема, його пасторальних тем-образів і поетичних мотивів) складає когнітивний план (пізнавально-мисленнєвий), тоді як інтерпретативний полягає в досвіді історико-культурного порівняння генетичного етапу європейської пасторалі (героїчного типу) з аналогічним початковим у практиці китайських композиторів XX ст. (кантата $\epsilon$ одним з перших професійних зразків жанру, що досяг визнання, в тому числі завдячуючи вибору героїко-пасторальної єдності в показі концепції світу та людини).

Виклад основного матеріалу. За музичною стилістикою твір належить до кантатно-ораторіального жанру. Про це свідчать великий склад виконавців (хор, оркестр), масштабні хори, урочисто-гімнічні мелодії, насичена оркестрова фактура, яскравий мелос в кантиленних частинах. Крім кантати, існує їі транскрипція в жанрі фортепіанного концерту з оркестром, зроблена піаністом Інь Ченцзуном. Перша, друга, четверта та сьома частини кантати складають основу драматургії концертного циклу. Нині ця версія є найвідомішим твором, найбільш виконуваним китайськими музикантами по всьому світу. Відмінністю між жанрами кантати і концерту є те, що партія фортепіано мислиться більш у західноєвропейському стилі та, стосовно фактурно-гармоніч- 
них і мелодико-ритмічних структур, апелює до концертної стилістики композиторів-романтиків (Ф. Ліста, С. Рахманінова).

Зважаючи на розвинену типологію сюжетів європейської пасторалі (кульмінацією якої був «галантний стиль» французького класицизму та рококо), вкажемо, що на етапі історичної генези (доба Бароко) найбільш актуальними для суспільної самосвідомості були зразки пасторалі героїко-патріотичного спрямування. Наприклад, в ораторіях Г. Ф. Генделя велику роль відігравали героїчні сюжети (античні або біблійні) та партія хору. Така семантика не має нічого спільного з жанром «великої ораторії» радянської доби 30-50 років ХХ ст., в якій панував одіозний дух прославлення партії та ії політики; як наслідок, фактично відбулась підміна понять: сакральна тематика ораторії поступилася фальшивій ідеології. На нашу думку, пасторальна концепція кантати китайського композитора Сянь Сінхая «Хуанхе» більше підходить до її суто музичного змісту: і автори твору, і його сучасні виконавці надихалися укоріненістю «букви та духу» твору в філософсько-поетичних ментальностях національної мови та мислення.

Музична семіосфера такого національно-визначеного явища, як «китайський образ світу» увиразнюється не тільки завдяки мовним засобам (лад, фактура, тембри народних інструментів), а, насамперед, завдяки етичним домінантам світоглядного мислення (філософії оспівування природи). Тематизм образів природи супроводжується «барвистою» імпресіоністичною гармонією, яскравими тональними співвідношеннями. Можна пригадати безліч творів та авторських обробок народних китайських пісень (автентичних або з кінофільмів), які об'єднує китайський дух (національний характер), притаманний і кантаті «Хуанхе» - для прикладу назвемо «Метелики», «Я люблю тебе, Китай», «Моя Батьківщина», «Маленький пастух».

Кантата як жанр європейської музики втілює етико-естетичний ідеал культурної самосвідомості музично-поетичними засобами (іноді перформативними). «Хуанхе» Сянь Сінхая на текст поеми Гуан Вейжаня не є винятком. Монументальний твір складається 38 частин. Є частини, де задіяні хор tutti (I, IV, VII, VIII), його жіночий склад (IV частина), чоловічий дует (V частина), соло тенора (I частина), соло баритона (II частина), соло сопрано (VI частина), соло 
піпи, тоді як партія читця (всі частини, окрім V) змістовно об'єднує твір. Використовується парний склад оркестру, але з трьома трубами, класичний склад струнних і арфа та китайські народні інструменти піпа, два сансьєни - великий (басовий) та малий (сопрановий); наявний великий вибір ударних (у тому числі й сім китайських народних інструментів).

Для кантатного твору специфічним є партія чития (як уособлення образу Поета), котра є однією з найвиразніших тембро-динамічних ліній (складових) наративної драматургії. Партія читця не лише увиразнює головну ідею твору, але й бере участь у розбудові його форми як наративно-об'єднуючий чинник. Цей прийом зустрічається в драматичних творах, театральних (оперних) виставах, сучасному кінематографі, наближуючи тим самим музичний жанр до перформансу. Кожна частина - наче «жива сцена» 3 тих важких, трагічних, вкрай величних для Китаю часів, за яких народ довів нездоланність свого патріотичного духу. Отже, поетичний текст дозволяє умовно вирізнити два драматургічних плани:

- той, щзо проговорюється (від першої особи - поета=автора) ведеться про те, що вже відбулося - час минулий (наратив, оповідь);

- той, щзо співається - про події «тут і зараз» - час теперішній (лірико-пасторальний спосіб оспівування, філософське споглядання природи).

3 програмної назви зрозуміло, що образи кантати пов'язані $з$ північною рікою, однією 3 найдовших у Китаї. Кожна частина циклу уособлює мінливий образ Хуанхе, води якої можуть бути спокійними, бурхливими, темними, прозорими, вони можуть як захищати, допомагати, так і топити. Хуанхе уособлює також ментальний символ ріки як колиски життя, бо й досі життя багатьох людей пов'язано з рікою: ловля риб та збирання мушель, вирощування лотосів для споживання ïх плодів (горіхів та коріння), прасування білизни, фестиваль драконових човнів на початку літа. В цілому в кантаті образ Хуанхе стає символом боротьби китайського народу з японськими загарбниками.

Твір пронизує національний китайський колорит, закладений у музичній стилістиці, насамперед, мелодиці, що свідчить про коріння художнього мислення композитора - суто національного, небай- 
дужого до своєї Батьківщини. Кожна частина кантати має декілька тем, які об'єднує ідея славлення, оспівування рідної землі та життя iї людей, в різних його вимірах: і в лірико-пасторальному спогляданні, і в розповіді про неспокійні, трагічні часи. Багато ознак свідчить про тяжіння композитора до звукозображальної символіки.

Однією з інноваційних рис твору є перехід від гетерофонії, притаманної народнопісенній традиції китайської культури, до європейських типів багатоголосся - гомофонно-гармонічного та поліфонічного. Це свідчить про вплив на композитора західного музичного мислення. Наприклад, абсолютно чужинне для китайської музики тяжіння до хроматизму в деяких моментах драматургічного розвитку кантати стає стилістичною нормою гармонічної мови.

Саме так починається перша частина - «Пісня човнярів Хуанхе» - 3 масивного, блискучого спуску хроматизмами - те, що завжди було «на маргінесах» китайської національної мови. Отже, раніше приховане чи абсолютно відсутнє стає першорядним. Перші такти твору є оркестровим дімінуендо - прикладом професіоналізму в методах роботи з тематизмом, на якому молоді композитори навчаються, яким чином можна будувати як вертикаль, так і горизонталь. Рух хроматизмами завершується початком звучання мелодії з ії коротких мотивних чарунок, що підкреслюється контрастом між інструментами тембровою рівновагою та протиставленням - arco та pizzicato струнних, звучанням арфи та мікстом гобоїв і кларнетів в унісон.

Цікаво, що деякі місця оркестровки, на наш погляд, не є «класичними»: це стосується закінчення ліній певними інструментами наприклад, лінія «ритмічної педалі» фаготів (тт. 8-9) закінчується на сильній долі, тоді як кінець подібної лінії кларнетів збігається в часі з початком мелодії; теж саме відбувається й у струнних. Втім, характер музики, започаткований у вступі, дає можливість цілком поринути в світ яскравих та могутніх почуттів, дух народу, а слова: «Друзі! Чи були ви на Хуанхе? Чи перепливали ви Хуанхе? Чи пам'ятаєте ви часи, коли ми боролися за наше життя на иій річці, мов ці величні хвилі? Якщуо ви забули, то слухайте!», - відразу ж дають зрозуміти, про що буде йтися далі. В партії хору чуємо вигуки «Хай-йоу!» та «Хуа-йоу!», що перекладається як «гребти веслом». 
Переможний піднесений стан можна визначити як героїко-пантеїстичний тип розповіді та порівняти з початком першої частини «Пісні про Землю» Г. Малера, але це більш світла музика, у якій радість виходить 3 берегів, мов води річки - tutti оркестру, швидкоплинний постійний рух музичної тканини, гліссандо арфи, партія хору, мова читця та соло тенора створюють монументальне звучання, а ладова основа (пентатоніка) підкреслює національний колорит.

Головна тема частини будується на коротких поспівках, але, окрім них, $\epsilon$ ще й лірична тема, що виступає в ролі побічної: вона контрастує з першою як типом мелодики (більш протяжної, пісенно-ліричної), прозорою фактурою, так і тембродинамікою: мелодія виконується спочатку струнними, потім - хором разом із дерев'яними духовими. Головна й побічна теми споріднені між собою інтонаційно-ритмічними зв'язками.

Друга частина, «Ода Хуанхе», переносить слухацьке сприйняття в інший вимір - світ споглядальних відчуттів, глибоких, наче води Хуанхе. Схожий ефект, започаткований у I частині - власне, іiі друга тема - тут постає на перший план. Після оркестрового вступу, як і в першій частині, читець задає тон, налаштовуючи слухачів на новий, більш спокійний лад. Головна тема проходить у партії віолончелей на тлі інших струнних та кларнетів (починаючи з затакту: т. 20). Основне тематичне навантаження має величне соло баритона. Партія арфи створює образ води, що рухається. За спостереженням автора статті, ця тема-образ $є$ однією з найулюбленіших у китайських слухачів. На наш погляд, це пов'язано з її ладо-гармонічною стилістикою, яка тяжіє до колористичності з м'якими гармонічними відхиленнями, протяжною пісенною мелодикою, що, певним чином, апелює до мелодичного стилю С. Рахманінова.

Третя частина, «Вода Хуанхе сходить з небес», починається 3 імпровізаційного соло піпи (китайського народного інструмента). На цьому тлі читець продовжує свою розповідь, яку розпочав у першій частині. Символи «квіточок» над нотами партії піпи позначають їх виконання в техніці тремоло. Імпровізація підготовлює вступ основної мелодії в партії піпи. Тут повністю відсутні хор та соло-голоси; основне семантичне навантаження - в словесному ряді читця та звучанні піпи. 
Четверта частина, «Балада Хуанхе», знов починається з промови читця, а згодом вступає хор - спочатку його жіночий склад, потім tutti. Жіночий склад хору завершує цю частину, утворюючи таким чином змістовну арку.

Вже від початку звучання першої теми п'ятої частини «Музичний діалог на берегу ріки» (чоловічий дует) - відчутно, що це - «точка перетину» в драматургії твору. Вона - єдиний розділ, де відсутня мова читця. Наявний тембровий контраст - п'ять китайських народних ударних інструментів (які широко використовуються в китайських операх), соло двох (великого та малого) сансьєнів, піцикато струнних, а в основу нової мелодії покладений більш гнучкий, бадьорий pух alla marcia. Це повністю контрастує попередній частині, в якій основна пісенно-лірична тема виконувалася жіночим складом хору.

Початок нової теми означений октавами та унісонами (мікстами) тембрів флейти, кларнета та сансьєна. У тематизмі цієї частини з'являється пунктир - ритмічна чарунка, яка створює певний ефект наступу / впевненості, що, в свою чергу, постулює головну ідею - боротьби із загарбниками, спротиву злу (у контексті кантати - засобами музики). Октавно-унісонне звучання при швидких шістнадцятих та гнучкому ритмі нагадує святкову музику.

Наступна шоста частина, «Плач Хуанхе», знову контрастує до попередньої, про що свідчать темпова позначка - pesante, мінорний лад (f-moll) та темброве забарвлення - соло сопрано.

Частина починається досить незвично з точки зору оркестровки: промова читця проходить на тлі перших скрипок, альтів та віолончелей, які грають мелодію в унісон. Напружений рух акордових сполучень та стрімкі пасажі вирізняють іï серед інших. Найдраматичніша сторінка кантати за концепцією нагадує Шостий номер кантати «Олександр Невський» С. Прокоф'єва, яка була створена того ж року (1939), що й кантата «Хуанхе». Ї̈̈ тематизм частково складає Третю частину Фортепіанного концерту Сянь Сінхая.

Сьома частина, «Захистимо Хуанхе», яка починається з партії читця, $є$ бадьорим, більш жвавим (ніж у V частині) маршем, що уособлює підняття народного духу. Вона містить одну з найбільш відомих 
тем кантати (мелодію цієї частини часто виконують молоді музиканти - вокалісти, піаністи, скрипалі, виконавці на арху, а також прості люди). Головна тема певною мірою схожа на «військову пісню» - малий барабан, труби, чітка та зрозуміла мелодія. Тематизм повністю діатонічний, але 3 модуляціями 3 тональності C-dur (перший розділ) до F-dur (другий розділ) та до Es-dur (третій розділ). Поетичний текст передбачає наявність читця та партії хору, без соло-співаків.

Восьма частина, «Лютий рев хвиль Хуанхе», починається з промови читця, яку змінює хорове tutti. В контексті всього твору ця частина, на наш погляд, має функцію певного «доказування», доповнення, бо надто масивною та «фінальною» $є$ попередня (фортепіанний концерт «Хуанхе» завершується саме на ній). У вступі повторюються хроматичні гамоподібні пасажі та пунктирні ритми, що вже зустрічалися в п'ятій та сьомій частинах твору. Тема проводиться діалогічно, як у першій частині, але тепер діалог відбувається між партією хору та оркестру. Знов згадаємо кантату «Олександр Невський» С. Прокоф'єва, яка за структурою певною мірою асоціюється 3 «Хуанхе» (зокрема, наявність жіночого соло в шостому та бадьорого маршу в заключному номері). Однак, якщо прокоф'євська кантата має саме сім номерів (трагічний № 6, бадьорий - № 7), то «Хуанхе» складається з восьми частин: трагічна шоста, бадьорий марш - сьома, i «доказування» (alla Coda) - восьма частина.

Отже, головною кульмінацією твору постає сьома частина i, у функції «доказування», - восьма, про що свідчить масштабний склад виконавців: оркестр з хором та, у вступах до частин - мова читця. В цих частинах вже відсутні соло вокалістів, як це було в експозиції (першій частині циклу).

Саме через впровадження хору можна виявити основні кульмінаційні зони кантати: хор задіяний у чотирьох з восьми частин - у першій, четвертій, сьомій та восьмій.

На Четверту частину припадає кульмінація, яка поділяє твір на дві масштабні «секції» по чотири частини:

\section{[I, II, III, IV] + [V, VI, VII, VIII] .}

В цілому, твір побудований таким чином, що, навіть не знаючи вербального перекладу, можна зрозуміти семантику частин циклу че- 
рез програмність мислення композитора, настільки колоритними та яскравими є теми й професійно побудованою - форма (відомо, що струнку та довершену форму створює саме контраст).

Контраст присутній на всіх рівнях музично-поетичної мови: вербального тексту, мелодії, гармонії, метроритму, тембро-динаміки, фактури, тобто проявляється системно.

Поетичний текст розподіляється між промовою читця, солістами, чоловічим дуетом та хором-tutti. Кожна частина починається декламацією читця, окрім П'ятої, оскільки, на нашу думку, використання в ній чоловічого дуету спонукало композитора не перетяжувати однаковим тембром музичну тканину, уникаючи схематичності в будові цілого. Унаочнімо виклад «драматургії» поетичного тексту партіями читця, хором та солістами (Таблиця 1).

Таблиця 1. Розподіл поетичного тексту між партіями в кантаті «Хуанхе»

\begin{tabular}{|l|c|c|c|c|c|c|c|c|}
\hline & I & II & III & IV & V & VI & VII & VIII \\
\hline Партія читця & $\boldsymbol{V}$ & $\boldsymbol{V}$ & $\boldsymbol{V}$ & $\boldsymbol{V}$ & & $\boldsymbol{V}$ & $\boldsymbol{V}$ & $\boldsymbol{V}$ \\
\hline Хор & $\boldsymbol{V}$ & & & $\boldsymbol{V}$ & & & $\boldsymbol{V}$ & $\boldsymbol{V}$ \\
\hline Жіночий склад хору & & & & $\boldsymbol{V}$ & & & & \\
\hline Дует тенора і баритона & & & & & $\boldsymbol{V}$ & & & \\
\hline Соло тенора & $\boldsymbol{V}$ & & & & & & & \\
\hline Соло баритона & & $\boldsymbol{V}$ & & & & & & \\
\hline Соло сопрано & & & & & & $\sqrt{ }$ & & \\
\hline
\end{tabular}

Тематичний контраст у творі виникає завдяки чергуванню у розділах та частинах коротких (I, III, VII частини) та довгих мелодичних фраз (II, VI частини). Безперечно, мелодика пов'язана 3 метроритмом, що створює відповідний характер висловлювання: бадьорий, жвавий (пунктири, короткі мотиви шістнадцятими), ліричний (повільні восьмі, чверті, половинні). Аналітично-слуховий досвід вивчення китайської музики дозволяє виокремити найбільш вживані ритмічні сегменти: 
- восьма - дві шістнадцятих (або навпаки);

- чотири шістнадцятих;

- чверть 3 точкою - восьма, або силабічно подібні їм ритмічні структури.

Ці базові ритмо-моделі є результатом багатовікової еволюції національної музичної мови Китаю, пов'язуючись, насамперед, із мовою вербальною, зі специфікою гри на народних інструментах (арху, піпі, гуджені, дідзі та ін.) та оригінальною традиційною нотацією, в якій досить проблематично використати дуже складні структури (як ритмічні, так і ладові).

Щодо фактурної будови, то композитор виходить за межі традиції - використовує гетерофонію, але, все ж таки, до монодічних структур вдається у певних «ланках» драматургії циклу (третій, п’ятій частинах). Фактурні комплекси вражають своїм розмаїттям, засвідчуючи тяжіння композитора до колористичного мислення в оркестровій тканині. Зазначимо, що в оркестровій тканині одним з найбільш показових контрастів є тембро-динамічний. За Г. Банщиковим (1999), тембр має дві функції - локальну та формотворчу, які досить майстерно проявлені в партитурі. Є частини, в яких задіяні китайські народні інструменти: піпа в третій, сансьєни та ударні в п'ятій. Простежимо темброву драматургію на прикладі вживання народних інструментів-соло - піпи, двох сансьєнів та китайських ударних (Таблиця 2).

Таблиця 2. Використання тембрів народних інструментів в кантаті «Хуанхе»

\begin{tabular}{|l|c|c|c|c|c|c|c|c|}
\hline & I & II & III & IV & V & VI & VII & VIII \\
\hline Оркестр & $\boldsymbol{V}$ & $\boldsymbol{V}$ & $\boldsymbol{V}$ & $\boldsymbol{V}$ & $\boldsymbol{V}$ & $\boldsymbol{V}$ & $\boldsymbol{V}$ & $\boldsymbol{V}$ \\
\hline Піпа & & & $\boldsymbol{V}$ & & & & & \\
\hline Сансьєн & & & & & $\boldsymbol{V}$ & & & \\
\hline Ударні & $\boldsymbol{V}$ & & & & $\boldsymbol{V}$ & & & $\boldsymbol{V}$ \\
\hline
\end{tabular}

Контраст діє й на рівні тональної драматургії кантати (Таблиия 3).

Аналітика, що міститься в таблицях, унаочнює, що при вивченні партитури кантати «Хуанхе» Сянь Сінхая маємо справу з концепту- 
альним мисленням її автора, яке, власне, й обумовлює драматургічну логіку твору. $Є$ частини, розподілені на контрастні розділи, що засвідчує й темпове різноманіття (Таблиця 4).

Таблиця 3. Тональний план твору

\begin{tabular}{|c|c|c|c|c|c|c|c|}
\hline I & II & III & IV & V & VI & VII & VIII \\
\hline D-dur & C-dur & D-dur & Es-dur & F-dur & $\begin{array}{c}\text { f-moll } \\
/ \text { As-dur }\end{array}$ & $\begin{array}{c}\text { C-F / } \\
\text { Es-dur }\end{array}$ & B-dur \\
\hline
\end{tabular}

Таблиця 4. Темпова драматургія кантати «Хуанхе»

\begin{tabular}{|c|c|c|c|c|c|c|c|}
\hline I & II & III & IV & V & VI & VII & VIII \\
\hline Vivace & $\begin{array}{c}\text { Comodo } \\
\text { /Andante }\end{array}$ & $\begin{array}{c}\text { Tempo } \\
\text { a piacere } \\
\text { /Animato } \\
\text { /Andantino } \\
\text { /Allegro } \\
\text { sostenuto } \\
\text { / Lento moto }\end{array}$ & Andante & Moderato & $\begin{array}{c}\text { Pesante } \\
\text { /agitato } \\
\text { /meno mosso }\end{array}$ & Allegro & $\begin{array}{c}\text { /Allegretto } \\
\text { /Maestoso } \\
\text { / tempo } \\
\text { di marcia } \\
\text { /Vivace }\end{array}$ \\
\hline
\end{tabular}

Отже, утворенню контрастів сприяє й темпова драматургія твору, яка, в свою чергу, діє й на рівні формоутворення.

Перша частина кантати має рондальну будову:

Вступ - A - B - $\mathbf{A}_{1}-\mathbf{C}-\mathbf{A}_{2}$, де В - мінорна, бадьора тема, а C лірична.

Друга частина складається зі вступу та великого соло баритона:

Вступ - A - B - C - $\mathbf{A}$.

Форма третьої частини складається з чергування двох тематичних розділів, що варіюються; деякі з них мають вільну будову через імпровізаційний характер партій піпи та читця: піпи.

Вступ - A - $\mathbf{A}_{1}-\mathbf{B}-\mathbf{A}_{2}-\mathbf{B}_{2}-\mathbf{A}_{3}$, де А - основна тема, В - соло

Четверта частина, що завершує перший «блок», написана в пісенній формі (зі вступом):

Вступ - $\mathbf{A}-\mathbf{B}-\mathbf{A}_{1}$, де «B» виконується tutti-хором та будується на матеріалі вступу.

П'ята частина написана в куплетній формі: $\mathbf{A}-\mathbf{A}_{\mathbf{1}}-\mathbf{A}_{\mathbf{2}}-\mathbf{A}_{\mathbf{3}}-\mathbf{A}_{\mathbf{4}}-\mathbf{A}_{5}$. 
Наративний зміст найдраматичнішої шостої частини викладено у варіантній формі крещендуючого типу.

Сьома частина починається зі вступу; іiі три розділи мають однакову тему, але у різних тональностях: $\mathbf{A}-\mathbf{A}_{1}-\mathbf{A}_{2}$.

Заключна восьма частина циклу складається з низки тем-мелодій, які утворюють вільну форму крещендуючого типу: $\mathbf{A}-\mathbf{B}-\mathbf{C}-\mathbf{D}-\mathbf{E}$ (Coda).

Перейдемо до аналізу мелодичної та ладогармонічної будови кантати. Ладогармонічні контрасти будуються на засадах класико-романтичної традиції, хоча і з національним «акцентом». Як вже було зазначено вище, тематизм кантати пронизує мелодичний первень, закладений у народній музиці. Основою $є$ п'ятиступеневий лад - пентатоніка. Однак у кожній частині $€$ певні відмінності.

Перша частина має декілька тем. Основна 3 них основана на мажорній пентатоніці від тону «d» (т. 48):

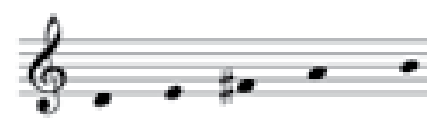

Наявні перегуки мелодичних мотивів у партіях соло-тенора та хору, що спираються на гармонію I та $V$ щаблів (автентичний зворот):

D-dur (I) ${ }^{8-9-8-9-9} \mid \mathrm{V}^{5-6-5}$. (Вкажемо на цікаве зіставлення - нову тональність E-dur (т. 66), що виконує функції $D D$ до основної тональності:

$$
\left.D \text {-dur } \mathrm{II}_{7}^{9-(8) 7-8-7} \rightarrow|\rightarrow| \mathrm{V}^{6-5}-\mid\right) \text {. }
$$

Друга тема мінорного нахилу (h-moll) починається без гармонічної підготовки (т. 73) шляхом зіставлення тональностей; чергування гармонічних сполучень відбувається вже не тільки між I та $\mathrm{V}$, але й між I та IV щаблями (плагальний зворот):

$$
\text { h-moll:\|: } \mathrm{I}_{(64)}-\mathrm{IV}_{6}\left|\mathrm{I}_{(64)}-\mathrm{IV}_{3}:\left\|: \mathrm{I}^{1-3}-\mathrm{V} \mid(\mathrm{V})^{4-3}-\mathrm{V}^{1-3}-\mathrm{I}:\right\| .\right.
$$

Якщо мінорна тема є лаконічною (період, 8 тактів), то третя тема (тт. 106-109), в основній тональності D-dur, мелодично та ладогармо- 
нічно пов'язана 3 першою темою, а також містить коротке зіставлення 3 тональністю fis-moll (т. 108), що приводить до домінанти основної тональності:

$$
\text { D-dur: } \|: \mathrm{I}^{8-9-8-6-5}:|| \mathrm{III}^{3-4}-\mathrm{II}_{6}\left|\mathrm{II}^{5-7}-\mathrm{V}\right| \text {. }
$$

Короткі мотиви, що в майбутньому стануть основою теми-мелодії сьомої частини, мають такий вигляд (т. 111):

$$
\text { D-dur: } \mathrm{V}^{8-9-8}\left|\mathrm{I}^{8-3-5-6-5}\right| \mathrm{II}_{6}\left|\mathrm{II}_{6}^{8-5-7-8-5}\right| \mathrm{VI}_{64}{ }^{4-1-3-4-1}\left|\mathrm{II}^{8-5-7}-\mathrm{V}\right| .
$$

Ладо-гармонічною основними цієї частини є чергування I-V, I-IV, I-III, I-VI, I-II щаблів. Можна відмітити діатонічне мислення композитора, яке спирається на вертикальні будови класико-романтичної традиції. Використані тональності з'являються за принципом зіставлення (без модуляційного ланцюжка).

Досліджуючи рівні організації другої частини кантати, бачимо, що іiї ладова основа - мажорна пентатоніка від тону «до» - звучить досить часто, втім гармонічна мова стає більш розвиненою.

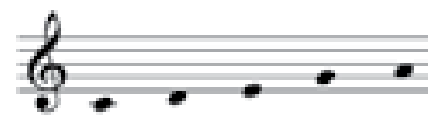

В чергу з тональним зіставленням з'являються модулюючі акорди та виразні звороти (наприклад, перерваний у тт. 20-21). Так, гармонічною структурою оркестрового вступу (тт. 19-23) до соло баритона є така послідовність акордів:

$$
C-\operatorname{dur}(\mathrm{I})_{1-2}\left|\mathrm{I}-\left[\mathrm{V}^{8-7-6} \ldots \mathrm{VI}\right]\right| \mathrm{IV}-\mathrm{V}^{6-5}\left|\mathrm{VI}-\mathrm{V}^{8-9-6-5}\right| \mathrm{I}_{5-6-3-2-1} \mid .
$$

Наведемо схему гармонічної будови, починаючи з соло баритона (тT. 23-38):

$$
\begin{gathered}
C-d u r(\mathrm{I})_{1-2}\left|\mathrm{I}-\left[\mathrm{V}^{8-7-6} \rightarrow \mathrm{VI}\right]\right| \mathrm{IV}\left|\left[\mathrm{V}_{64} \rightarrow \mathrm{II}_{6}^{\# 3}\right]\right| \mathrm{V}|\mathrm{I}| \mathrm{I}_{6}|\mathrm{I}-[\mathrm{V} \rightarrow \mathrm{III}]| \mathrm{VI}-\mathrm{I}_{64} \mid \\
\mathrm{II}_{6}-\mathrm{V}_{6} \rightarrow\left|\mathrm{II}_{1-2}-\mathrm{V}_{65}-\mathrm{VI}\right| \mathrm{II}_{65}{ }^{-5}\left|\mathrm{III}_{6}\right| \mathrm{II}_{65}^{+1+3}-\mathrm{I}_{64}\left|-\mathrm{V}-\mathrm{VI}^{5-7-5}\right| \mathrm{V}_{6} \mid
\end{gathered}
$$


Порівнюючи гармонічну мову I та II частин кантати, вбачаємо відмінність, що продиктована різним мелодичним та жанровим змістом: у першій частині - короткі, активні мотиви (героїка), у другій розлоге дихання (пасторально-лірична оповідь).

Ладову структуру третьої частини можна трактувати з різних позицій. В імпровізаційному вступі в партії піпи знаходимо низку цікавих речей. Мелодія починається з варіювання навколо звуку «d» (щаблі $D$-dur): \|: 3-2-1:\|:(3-2)-1-2-1-5 :\|: 1. . \|, що вказує на мажорну пентатоніку:

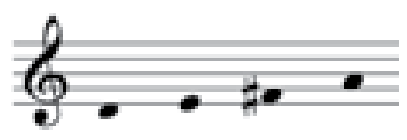

Згодом звучить перехід до звуку «с²», відсутній у мажорній пентатоніці від «d»:

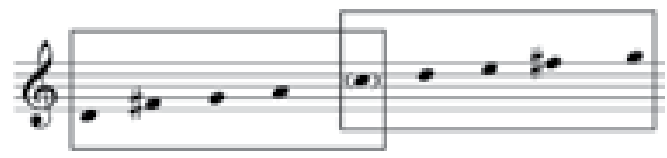

Таким чином, створюється ефект міксолідійського ладу, або лідійського від тону «с». Після цього виникає звук «до\#», як третій щабель домінанти D-dur, але новий звук «ре\#» знову вказує на міксолідійську спрямованість, а згодом - на присутність цілотоновості, що приводить до утворення мажоро-мінорної пентатоніки. Звідси виникає ефект «мерехтливого», нестійкого ладу.

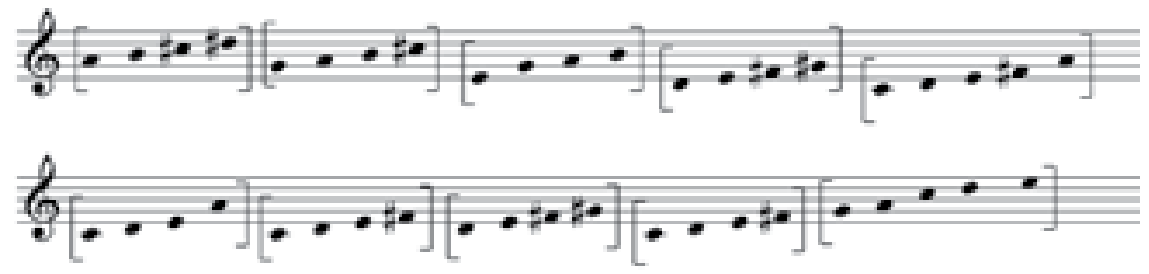

Основна тема має грайливий характер, що підкреслює іiі ритміка, та викладається спочатку в мінорній пентатоніці від «ля», 
далі - від «ре», в гармонічному супроводі низьких струнних. Ці лади вживані не випадково, вони відповідають специфіці гри на піпі, іiі стрій - A-d-e-a:

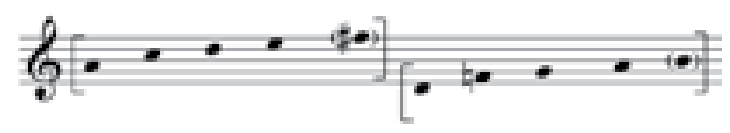

Далі йде розділ, де піпа не задіяна (тт. 23-45). Тема, що прозвучала у піпи, в новому розділі викладається більш розгорнуто. Гармонічна будова та фактура певною мірою нагадують попередні ліричні частини з фігураціями арфи, й вже не презентують чогось цілком нового, окрім мелодії, як свідчить гармонічна схема (тт. 23-34):

D-dur: $\mathrm{I}^{6}|-| \mathrm{I}_{6}{ }^{5-6}\left|\mathrm{VI}^{3-4}\right| \mathrm{I}^{6}-\mathrm{VI}\left|\mathrm{V}^{4-9}\right| \mathrm{VI}\left|\left[\mathrm{V}^{8-9-9-8} \rightarrow \mathrm{VI}\right]\right| \mathrm{IV}|\mathrm{III}| \mathrm{II}_{65}-\mathrm{II}_{7} \mid \mathrm{V}_{9}$.

Знов з'являється імпровізаційна партія піпи-соло, в більш насиченій та рухливій фактурі (тт. 46-78). Кварто-квінтові сполучення, 3 яких складається цей розділ, відповідають, знову ж таки, строю піпи та специфіці гри на ній. Ладо-гармонічна будова цього розділу так само цікава, як і у вступі. Органний пункт на звуках «а-d-е» на початку мелодії вносить відтінок міксолідійського ладу. Цікаво, що композитор дає перехід до справжнього Ре-мажору (але з мінорною домінаною) через мажорну домінанту (т. 77), вкрапляючи в музичну тканину піпи звук «до\#».

Наступний розділ повертає слухача до другої мелодії, але тепер, за логікою накопичення та динамізації; основна мелодія викладена в партії піпи, а далі - валторни соло. Так відбувається пересемантизація образу - домінує пастораль. Саме в цю жанрову сферу «модулює» героїка. Далі повертається імпровізаційний соло-розділ піпи (т. 101) у скороченому вигляді (15 тактів). Завершує частину розвинений оркестровий розділ.

Ладогармонічна будова четвертої частини містить деякі риси тональної системи, а саме - автентичний каданс (4-й такт в партії валторни соло): 


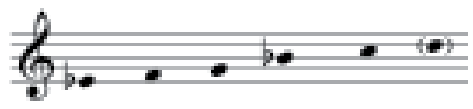

$$
\text { Es-dur: }(\mathrm{I})^{1}-(\mathrm{V})^{3} \mid(\mathrm{I})^{1}
$$

а також зіставлення (тт. 6-10):

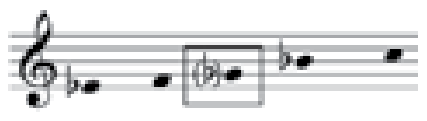

$$
\begin{aligned}
& \text { Es-dur: } \mathrm{I}_{6}^{5-6} \mid\left(\mathrm{I}_{6}^{-3)}\left|\mathrm{II}^{8-7}\right| \mathrm{II}_{7}^{+1-+3} \mid \mathrm{I}_{6}\right. \\
& \text { es-moll } \mathrm{I}_{6}
\end{aligned}
$$

У цій частині втретє задіяна фігуративна партія арфи.

Ладогармонічна основа п'ятої частини також спирається на пентатоніку, але з деякими відхиленнями всередині звукоряду (хроматизм між V та IV щаблями). Основою слугує мажорна пентатоніка від тону «f»: f-a-b(h)-c-d. Цей «мерехтливий» хроматизм (F-dur): V - IV - V) та пунктир надає тематизму нестандартного звучання.

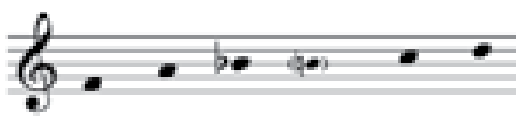

У шостій частині, як й в інших, класико-романтичне звучання створює саме вертикаль - гармонія, оскільки ладове нахилення $\epsilon$ незмінним:

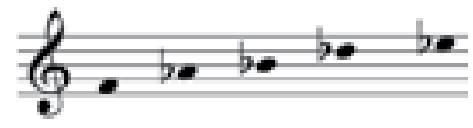

Мелодична та ладогармонічна стилістика сьомої частини кантати будується на зіставленнях діатоніки мажоро-мінорного складу (тт. 3-4) та пентатоніки (тт. 5-6), відчутної у вступі: 


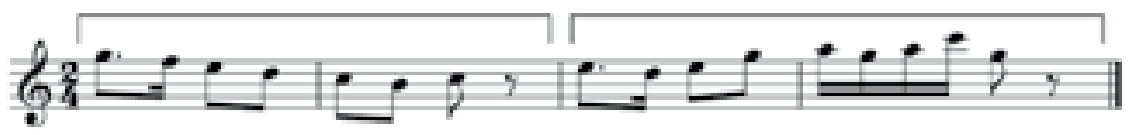

У головній темі переважає мелодичний рух по звуках тризвуків (I та II щаблів) та мелодичне оспівування стійких щаблів (тт. 17-28):

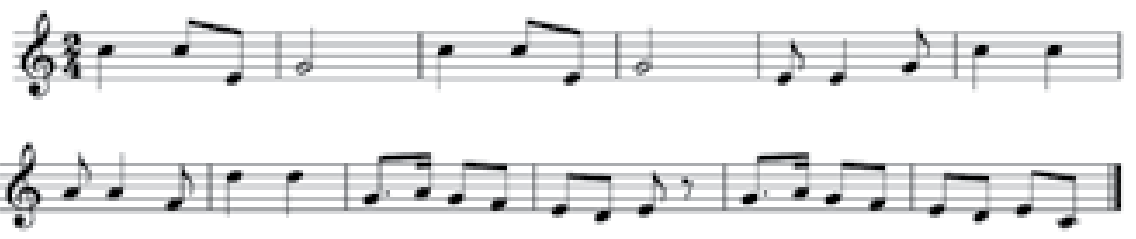

Ладогармонічною основою є діатонічний принцип організації (тт. 17-33):

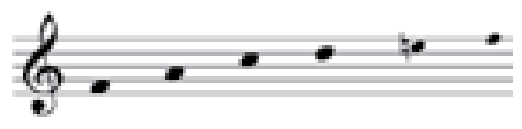

C-dur: $\mathrm{I}|-|-|-| \mathrm{II}|-| \mathrm{V}^{8-9-8-7}\left|\mathrm{VI}_{7}-\mathrm{V}_{6}-\mathrm{I}-{ }_{6}\right| \mathrm{V}^{8-9-8-7}\left|\mathrm{VI}_{7}-\mathrm{V}_{6}-\mathrm{I}\right| \mathrm{I}_{6}{ }^{5-6}|\mathrm{VI}|$ $\mathrm{I}_{64}^{5-10-9-8}|\mathrm{~V}| \mathrm{V}^{8-9} \mid \mathrm{I}$

Мелодика восьмої частини будується як на пентатоніці (тт. 1-11), так і на мажоро-мінорній основі - вступ до головної теми й тема у партії хору (тт. 31-37):

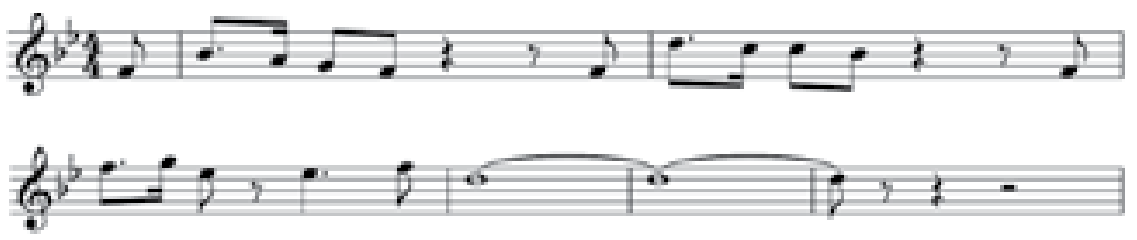

Гармонічну організацію відображає схема (тт. 31-39):

$$
\begin{aligned}
& \text { B-dur: } \mathrm{V} \mid \text { (I) }^{8-7-6-5-} \mathrm{I}-\mathrm{V}\left|(\mathrm{I})^{3-2-1}-\mathrm{I}^{2-1}-\mathrm{V}\right| \mathrm{I}^{5-6}-\mathrm{II}-\mathrm{II}-\mathrm{VII} \mid \\
& \text { G-dur: } \mathrm{II}_{7}^{-5-6}|\mathrm{~V}|-|-|-\mathrm{I}-\mathrm{II}_{64}-\mathrm{V}_{6} \mid \mathrm{I} .
\end{aligned}
$$


Згідно з наданим аналізом основних рівнів музично-тематичної структури можна стверджувати, що взаємовідношення між ними обумовлено впливом західноєвропейського (тонально-функціонального) мислення на національне (китайське) підгрунтя музичної мови. Особливо це стосується ладогармонічної та фактурно-тембрової будови твору. На пентатоновий лад наче «накладається» трафарет класичної гармонії, що організує фактуру за законами гомофонії, яка не притаманна китайській народній пісні.

Висновки. I. Характерними рисами музичної мови кантати є:

1) наратив героїко-патріотичного типу: масштабність оповідання; емоційність показу картин народного життя;

2) пісенний первень (широкі мелодичні лінії у повільних частинах);

3) тяжіння до діатоніки;

4) мотивний тип розвитку;

5) тональні зіставлення;

6) усталені ритмічні формули,
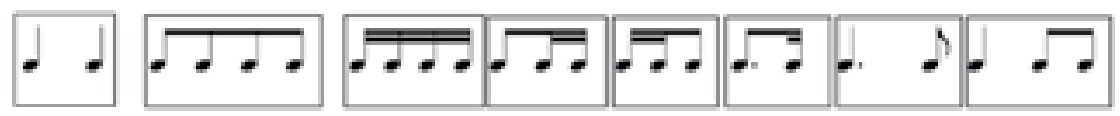

що є архетиповими (запозиченими з фольклору);

7) контраст як принцип організації драматургії твору за такими рівнями: а) тембр (класичні інструменти - китайські народні інструменти); б) принцип супідрядності вербального та музичного тексту: мова - спів; в) діалог (полілог) як принцип трактування хору та його складових: хор - жіночий склад - чоловічий дует - соло; г) фактурний виклад: соло (піпа) - оркестр; монодія - гомофонно-гармонічний склад; д) принцип ладогармонічного мислення: хроматика - діатоніка; пентатоніка - тональність.

II. Жанрові ознаки пасторалі виявляються у прагненні композитора до звукозображальної символіки, пов'язаної з образами природи, які посідають паритетне місце поряд з піднесено-патріотичними образами. В цілому трактування концепції кантати як героїчної 
пасторалі збігається з бароковою моделлю екзистенції європейського жанру (ораторії Г. Ф. Генделя «Самсон», «Іуда Маккавей» та інші). На цьому грунті формується модель жанру з комплексом усталених елементів музичної мови та семантикою образу людини пасторальної. Національно-означеними прикметами китайської пасторалі є колективний герой (народ), пантеїзм як філософія любові

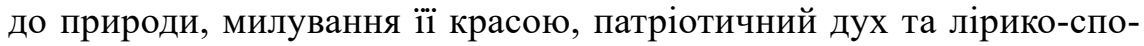
глядальний світогляд (за контрастом із суспільно-етичними проблемами буття).

Перспективу подальшого вивчення теми обумовлює затребуваність в практиці китайських співаків інших зразків пасторальної «гілки» вокальної музики, що розповсюджена в творчості китайських композиторів (жанрові різновиди пейзажної, любовної, філософсько-споглядальної пасторалі) і тому має буди дослідженою в наступних наукових розвідках.

\section{ЛІТЕРАТУРА}

Банщиков, Г. (1999). Законь функциональной инструментовки. Санкт-Петербург: Композитор.

Шаповалова, Л. В. (2017). Интерпретология как интегративная наука. Проблеми взаємодії мистеиттва, педагогіки та теорї і практики освіти, 46, 289-300.

Chang, Chun-ya (2017). The Yellow River Piano Concerto: a pioneer of Western classical music in modern China and its socio-political context. (DMA thesis). The University of Alabama. Tuscaloosa. Retrieved from http://ir. ua. edu/ handle/123456789/3378

Shan Bai (2006). The historical development and a structural analysis of the Yellow River Piano Concerto. (Master thesis). University of Pretoria. Pretoria. Retrieved from https://www. matsuk12. us/site/handlers/filedownload. ashx? moduleinstanceid $=11065 \&$ dataid $=27017 \&$ FileName $=$ Yellow\%20River\%20 Analysis. pdf

Shapovalova, L. \& Chernyavska, M. \& Govorukhina, N. \& Nikolaievska, Yu. (2021). Pastoral in instrumental and vocal music 18-21 centuries: genre invariant and performance. Ad Alta: Journal of interdisciplinary research, 11 (2), special iss. XX, 136-140. 
Проблеми взаємодії мистецтва, педагогіки та теорії і практики освіти, вип. 60147

Tao, Lin (2019). An Integration of East and West: History, Analysis and Reception of the Yellow River Piano Concerto. (DMA dissertations). Louisiana State University. Baton Rouge. Retrieved from https://digitalcommons. lsu. edu/ gradschool_dissertations/5059/

Xiangtang Hong (2009). Performing the Yellow River cantata. (Dissertation for the degree of DMA). University of Illinois at Urbana-Champaign. Urbana, Illinois. Retrieved from https://www. ideals. illinois. edu/bitstream/ handle/2142/14552/1_hong_xiangtang. pdf? sequence $=3$

\section{Huang Lei}

Postgraduate student at the Department of Interpretation and Music Analysis, Kharkiv I. P. Kotlyarevsky National University of Arts e-mail: 1908278607@qq.com

ORCID iD: 0000-0001-9227-8429

\section{HEROIC PASTORAL AND ITS NATIONAL-STYLE RECEPTION IN THE CANTATA "YELLOW RIVER" BY XIAN XINGHAI}

The statement of the problem. The cantata “Yellow River" (黄河) is one of the most expressive works in Chinese musical art. The article offers interpretation of the cantata in the light of national Chinese pastoral symbolism. Created in 1939 by Xian Xinghai (冼星) and based on the text of a poem by Guang Weizhan (光未然), the cantata is still of great interest to the researchers.

The poetic text of the cantata tells about hard struggle of the Chinese people against the Japanese invaders during the Second Sino-Japanese War.

The Ukrainian listeners are faced with misunderstanding of the musical language and cultural norms of Chinese mentality. The artistic concept of pastoral genre as a harmonious communication between man and nature makes it possible to interpret the ethno-national language of this work in the system of European values. Rather, we can talk about a historical and cultural parallel corresponding to the "dialogue of cultures" as a leading trend in contemporary art and not about stylization. Heroism of European Baroque and Classicism was closely associated with the image of a person fighting for the social ideals (and even dying for 
them), while the pastoral emphasized images of nature, which served as excellent "scenery" for human actions.

The relevance of the article increases interest in the problem of human communication in the globalized oecumene, in particular, in the composer's interpretation of the cantata genre semantics in relation to a concept of "heroic man" and idea of pantheism as a philosophy of a pastoral man.

The purpose of the article is to identify the established dominants of the Chinese national language in the cantata "Yellow River" by Xian Xinghai in the context of pastoral genre symbolism.

Number of scientific publications investigate this piece, yet none of them addresses the issue of cantata genre semantics as a national reception of heroic pastoral. Thus, Shang Bei's dissertation revealed the principle of constructing the Yellow River piano concerto, borrowed from the thematism of the cantata (the second section of the dissertation is devoted to the cantata itself, and the third - to the concerto). Xiangtang Hong's (2009) dissertation explores the history of the cantata, its verbal text, Western European influences.

Analysis of recent research and publications. Cantata as a genre and form of European music embodies a certain ideal of cultural identity through musical and poetic means. "The Yellow River" is no exception. The composition consists of 8 parts. There are parts where there is a tutti chorus (I, IV, VII, VIII), its female composition (IV), male duet (V), solo tenor (I), solo baritone (II), solo soprano (II), solo soprano (VI), solo pipa and the reader's part (all parts except V), uniting all movements. The cantata uses a paired orchestral composition, but with three trumpets and solo parts for Chinese folk instruments - pipa, two sanshinas large (bass) and small (soprano). There is a large percussion section (including seven Chinese folk instruments), harp and classical string section. The article emphasizes the role of the reader, who personifies Poet and becomes one of the most expressive timbre-dynamic lines of the music piece. The reader's part not only reveals the patriotic idea of the work, but also contributes to the development of its form as a unifying element. This technique found in drama productions and modern cinematography made musical genre closer to the performance. Each movement is a "live scene" depicting extremely tragic times for China, when people proved the invincibility of their spirit. The poetic text makes it possible to distinguish two dramatic dimensions in the cantata: the one in which the Poet (the image of the Author) speaks of what has already happened and the second 
one glorifies the current events "here and now". Each movement of the cantata portraits the changing image of the Yellow River, the waters of which can be calm, stormy, dark and transparent. The work is filled with national stylistics embedded in melodic-rhythmic and modal structures. Each movement of the cantata has several themes united by the idea of glorifying the native land and its people in different dimensions: lyrical contemplation (pastoral), stories about tragic times (narration) and singing about people (ode).

Conclusions. One of the innovative principles of musical thinking is the shift from heterophony inherent in the Chinese folk song tradition to homophonicharmonic and polyphony. This proves the influence of Western European musical thinking. For example, the attraction to chromaticism, completely alien to Chinese music, at some stages of the dramatic development of the cantata becomes one of the stylistic features of its harmonious language. This is how the first part of "The Song of Boatmen on the Yellow River" begins - with a massive, brilliant chromatic descent. Thus, first of all, the hidden or the absent becomes paramount.

The article notes the technique of timbre mixes of folk and symphonic instruments, which signals a professional work oncthematicism based on genrestylistic synthesis. The genre features of pastoral are revealed in the composer's tendency towards sound-imaging symbolism associated with images of nature, which are equivalent to heroic images. In general, the interpretation of cantata as a heroic pastoral coincides with the early (baroque) stage of the genre in Europe (oratorio by G. F. Handel), which formed a complex of invariant elements in musical language, emphasizing genre semantics (the image of the "shepherd"). The work exposes the national features of the Chinese pastoral - a collective hero (people), heroic pathos, pantheism as a philosophy of love for nature, a lyrical and contemplative worldview.

Key words: cantata; artistic concept of genre; heroic pastoral; narrative drama; sound-imaging symbolism.

\section{REFERENCES}

Banshchikov, G. (1999). The laws of functional instrumentation. St. Petersburg: Compozitor [in Russian].

Chang, Chun-ya (2017). The Yellow River Piano Concerto: a pioneer of Western classical music in modern China and its socio-political context. (DMA thesis). 
The University of Alabama. Tuscaloosa. Retrieved from http://ir. ua. edu/ handle/123456789/3378 [in English].

Shan Bai (2006). The historical development and a structural analysis of the Yellow River Piano Concerto. (Master thesis). University of Pretoria. Pretoria. Retrieved from https://www. matsuk12. us/site/handlers/filedownload. ashx? moduleinstanceid $=11065 \&$ dataid $=27017 \&$ FileName $=$ Yellow $\% 20$ River $\% 20$ Analysis. pdf [in English].

Shapovalova, L. V. (2017). Interpretology as an integrative science. Problems of interaction of art, pedagogy and theory and practice of education, 46, 289-300 [in Russian].

Shapovalova, L. \& Chernyavska, M. \& Govorukhina, N. \& Nikolaievska, Yu. (2021). Pastoral in instrumental and vocal music 18-21 centuries: genre invariant and performance. Ad Alta: Journal of interdisciplinary research, 11 (2), special iss. XX, 136-140 [in English].

Tao, Lin (2019). An Integration of East and West: History, Analysis and Reception of the Yellow River Piano Concerto. (DMA dissertations). Louisiana State University. Baton Rouge. Retrieved from https:/digitalcommons. 1su. edu/ gradschool_dissertations/5059/ [in English].

Xiangtang Hong (2009). Performing the Yellow River cantata. (Dissertation for the degree of DMA). University of Illinois at Urbana-Champaign. Urbana, Illinois. Retrieved from https://www. ideals. illinois. edu/bitstream/ handle/2142/14552/1_hong_xiangtang. pdf?sequence=3 [in English].

Стаття надійшла до редакиії 12 вересня 2021 р. 